\title{
Showing Your Value
}

Amongst my fellow technical communicators and usability specialists, I often hear complaints that we don't receive the respect we deserve. I hear worries about being underpaid for our contributions and being exploited internationally.

The best response to these fears and to any reality behind them is to ensure that we are not only providing value to our companies and clients, but also are showing them that value. Making others aware of our value is not only unique to us. People in all fields are obliged to do the same. For example, professors are "selling" their theories and the value and magnitude of their data whenever they speak at a conference or within the context of their written studies.

How do we provide value? And how do we show that value?

\section{Understand what your companies or clients value}

In any business setting, the first step is to find out what matters to the people who appreciate your value. This is usually money. Managers and executives value financial success.

It may not only be money. Many companies also value

- Customer satisfaction, because it usually leads to a greater market share

- Awards, so that they can advertise themselves to different people.

- $\quad$ Stories as they can be a great form of Public Relations.

\section{Understand how you contribute to what they value}

The second step is figuring the clockwork of the work you do. How does your work make a difference in ways that matter to the people whom you must convince of your value? Contributions to financial success are better explained in a cost-benefit equation. You provide value when the benefits you bring are greater than what you and your work cost the company or client. A cost-benefit equation shows a return on investment (ROI). Your work makes positive contributions to ROI either by increasing benefit or reducing costs. The relevant measures depend, of course, on your company or client's field of business. Table 1 (adapted and updated from Redish, 1995 [2003]) shows some of the ways your work may be contributing to the financial success of your company or 
client.

Table 1.

Some measures of the value that technical communicators and usability specialists bring to companies and clients

Measures that show increased Measures that show reduced costs benefit

\begin{tabular}{|c|c|}
\hline - More sales & $\begin{array}{l}\text { - Fewer support calls; lower support } \\
\text { costs }\end{array}$ \\
\hline $\begin{array}{l}\text { - Increased conversion rate - such } \\
\text { as filling out forms reached } \\
\text { through online ads or sponsored } \\
\text { links }\end{array}$ & $\begin{array}{l}\text { - Less need for training; lower } \\
\text { training costs }\end{array}$ \\
\hline $\begin{array}{l}\text { - Increased productivity; shorter } \\
\text { time on task }\end{array}$ & - Less downtime for workers \\
\hline $\begin{array}{l}\text { - More documents retumed quicky } \\
\text { and completed correctly } \\
\text { (especially forms) }\end{array}$ & $\begin{array}{l}\text { - Fewer requests for maintenance; } \\
\text { lower repair costs }\end{array}$ \\
\hline $\begin{array}{l}\text { - More potential problems with the } \\
\text { product identified and resolved } \\
\text { early }\end{array}$ & $\begin{array}{l}\text { Less effort (time, lines of code, } \\
\text { rework) needed when technical } \\
\text { communicators are involved early } \\
\text { than when they are not }\end{array}$ \\
\hline - More proposals won & $\begin{array}{l}\text { - Lower costs for paper, printing, } \\
\text { etc. because technical } \\
\text { communicators wrote less with } \\
\text { equal or better results }\end{array}$ \\
\hline $\begin{array}{l}\text { - More people installing and using } \\
\text { the product }\end{array}$ & $\begin{array}{l}\text { - Fewer errors (by devel opers using } \\
\text { specifications, by clerks reviewing } \\
\text { forms, by users installing } \\
\text { products, etc.) }\end{array}$ \\
\hline $\begin{array}{l}\text { - More patients taking their } \\
\text { medicine as prescribed }\end{array}$ & - Fewer grievances; less litigation \\
\hline $\begin{array}{l}\text { - More people who are entitled to a } \\
\text { benefit completing the process to } \\
\text { get it }\end{array}$ & \\
\hline
\end{tabular}

\section{Think broadly about your contributions}

Technical communicators provide value not only by writing pages and pages of documentation (for print, online, or both). Usability specialists provide value not only by running days and days of usability tests. Those are the commodities that can most easily be sent elsewhere. As Thomas Friedman once said in The World is Flat, we must all try to find work that "can't be outsourced, digitized, or automated" (Friedman, 2006, 278). "The people who will keep their jobs", says Friedman, are the synthesizers, the explainers, and those "capable of not only constantly adapting, but also learning and growing" (ibid., 289). 


\section{Saving money by producing less}

In fact, if you are a technical communicator, you may want to show that you contribute by preventing the company from needing pages and pages of documentation. If you provide innovative ideas for successful communication whilst saving time and materials, it is seen as a great contribution to ROI.

This is exactly what Al Blackwell and his team at the SABRE Travel Information Network did. Instead of writing the 150-page manual that the developers assumed would be necessary, they realized that the product - an online help system - would need just a short installation guide. Surveying users later pointed out that they were right. With this short guide, people actually installed and used the new online help system. And that, in turn, greatly reduced calls to the help desk. A double win. (Blackwell, 1995)

\section{Bringing in money by changing the type of document}

Technical communicators think. They don't just write. Thinking about their audiences and the ways that their audiences use documents can help to create the right document for the right situation.

Writers at the Washington State Department of Revenue proved this. Unlike the VAT that many European countries include in the cost of goods, sales tax in most U. S. states is added to the purchase at the time of purchase. When you buy over the Internet or by phone, the purchase often comes without tax. The Internet site or catalogue company does not wish to deal with collecting and paying tax at different rates to many different states. In Washington State, companies are supposed to report these purchases and pay the appropriate state tax themselves to the state government. Many were not doing so. The state's first attempt to get companies to pay was to send a Special Notice in typical government language. Ninety-seven percent of businesses ignored it. The writers then considered how to capture the attention of the very busy business people.

The writers rewrote the "notice" as a letter, addressed by name and tax ID number to each business owner. They wrote the letter in plain language with effective headings. The Washington State Department of Revenue ended up collecting $\$ 800,000$ more than the goal the state had set for revenue from this tax.

\section{Saving money by being involved early and changing the product}

Technical communicators and usability specialists help make products intuitive. When they influence the interface, they can 
greatly improve productivity and satisfaction for customers.

This is what Christine Yates, head of usability in the Forms Unit of HM Revenue and Customs in the UK did with a tax return. Until recently, everyone in the UK who reported taxes did so on a long return. Many people didn't need the entire form, and someone suggested creating a shorter one. The forms could have just been cut with minus some questions out of the long return, but Yates took the initiative and added value. Yates rewrote the return, simplifying the language and taking it through iterative usability testing. The work paid off. In a recent survey (Bolling, 2006), the long return received satisfaction ratings of $79 \%$ for ease of understanding and $83 \%$ for ease of completing. The short return received ratings of $95 \%$ on ease of understanding and $96 \%$ on ease of completing. People completed the short return in half the time that the long return took to complete. Part of that difference is probably due to the fact that it is shorter; but part of the difference is probably due to the value of Yates' work. One can imagine how this translates into cost savings, such as fewer forms needing corrections, fewer forms sent back for being incomplete etc. Has one ever rated a tax form at $96 \%$ for ease of understanding?

\section{Find a way to measure your value}

The third step is to measure your value in ways that bear a relation to the people who must appreciate that value. What you can measure, and how you can measure it depends on the context. This includes the type of product, the medium in which it is used, the users, and so on. Here are just a few ideas for you:

\section{Comparing "before" and "after"}

An excellent way to show value is to be able to compare a situation prior to involvement with the "after" - the effect of your involvement.

\section{Making web users more successful.}

In many web revision projects, usability specialists are beginning to take a baseline measure at the beginning of a project so that they can show at the end of the project how much their work has helped improve the web site. When the U. S. Department of Health \& Human Services realized that they needed to revamp the top levels (home page and navigation pages) of their web site (www.hhs.gov), they turned to a usability team within the department. The usability team started with a baseline usability test. After six months of an interactive user-centered design process, having worked closely with content specialists, the team revised the home page and created new navigation pages. Finally at the end of the process, a 
similar usability test was conducted. Five scenarios were identical in both the baseline and final test. These results gave them a clear comparison. Table 2 shows the success people had with the new site. Table 3 shows the comparison between the same scenarios before and after. (Theofanos, Mulligan, and Redish, 2004; Theofanos and Mulligan, 2006)

Table 2.

Success with the new site at www.hhs.gov

\begin{tabular}{l} 
Note: 16 people each doing 12 tasks, thus 192 attempts \\
$\begin{array}{l}\text { Getting off the home page onto a good path } \\
\text { Getting off the next navigation page still on } \\
\text { a good path }\end{array}$ \\
\hline
\end{tabular}

Table 3.

Comparing the same tasks at www.hhs.gov

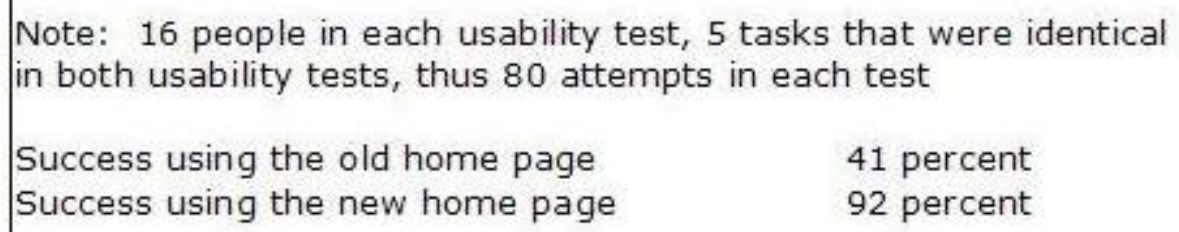

\section{Increasing conversion rate.}

For companies that conduct business by getting people to click on ads or sponsored links, "conversion rate" is an important measure. For a loan brokerage company, the conversion rate is the percentage of people who complete and submit their form compared to those who arrive at the form. You can compare conversion rates for several versions of the same web page easily because you can serve up different versions in rotation from the same ad or sponsored link. Caroline Jarrett, a UK usability and forms consultant, helped CompareInterestRates.com to try several different ways of to increase its conversion rate. The one that was most efficient was to change paragraphs of text at the top of the form into a bulleted list - typical of what a technical communicator might suggest. Overall, Jarrett helped her client achieve increases of $50 \%$ and $25 \%$ in two different streams of traffic (Jarrett and Minott, 2004). 


\section{Comparing across situations}

Sometimes, you can take advantage of situations that allow you to compare across similar products or projects.

\section{Reducing support costs through good documentation.}

Although this story started out as a potential problem, it ended up as a way for technical communicators at General Electric Information Services (GEIS) to show the value of their work. It started when the customer support center told Cathy Spencer, the technical communications manager, that they were fielding many calls on a particular product. Spencer knew her folks had written good manuals for that product and did a good job of customizing them for different clients. Spencer had the support center further investigate the data on these calls further. It turned out that the calls were coming almost entirely from one customer - a customer who had insisted on customizing their own manuals rather then having the GEIS technical communicators do the work. By then, comparing the costs of supporting the client who was not in fact using the GEIS technical communicators' work with the lower costs of supporting clients of a comparable size (who were actually using the GEIS manuals,) Spencer was able to show how much money her folks were saving the company. (Spencer and Yates, 1995).

\section{Getting more work by showing value.}

A technical communication group that I was once mentoring realized that they could use their situation to demonstrate value. Two lines of business were supposed to be supported. However, the two business managers treated them very differently. One regularly involved them in projects. The other did not. How could they get the manager that did not see them as important to give them the work they were supposed to be doing? This was done by finding ways to compare similar products from the two lines. For example, how many support calls were each generating? What were sales reps reporting about the customers' perceptions of the documentation?

\section{Make sure people know about your value}

The fourth step is to increase awareness of the value that you bring to your company or client. It's not enough to contribute. If you want respect, interesting work, and better pay, the people who have to appreciate your value need to know about it. You have to show your value and create the business case-scenario for it.

\section{Convincing engineers that you save them time and effort}

In the mid 1990s, John Gabbert needed more resources to produce 
documentation for the small hardware company he worked for. The engineers didn't think that was needed because they didn't see any problems with the current documentation. The company did not have a separate customer support center; the engineers answered whichever calls came in about their products. Gabbert convinced the engineers to track calls for a month, using a simple form he created. The engineers noted the time each call started, the reason for the call, whether the person should have been able to solve the problem by using documentation, and the time each call ended. When the month was over, the engineers' attitudes had changed radically. The engineers realized how much time they were spending on these calls; how much these calls were costing the company; and how better and more attractive documentation might help. (Gabbert, 1996).

\section{Selling usability by making managers empathize with users}

I often help people bring usability and user-centered design into their company through interactive short courses. In one case, some people in a U. S. government agency were trying to get upper-level management to understand the need for and the power of usability testing. I was brought in to teach an introduction to usability testing. I insisted, as I always do, that we run an actual usability test with something they were developing. A software program was selected that was just about to be introduced. Managers would have to use this software to track certain data about their employees. A senior manager volunteered to be the usability test participant in our case-study test session. After half an hour of participation in the test session, he was ready to sign off on the cost of creating a usability lab and to fight for getting usability specialists into the agency.

\section{Working with numbers}

You may need to have numbers to make the case in your company or with your client. As Mead (1998) points out, this requires good management and budget-tracking processes in place. Mead gives guidance on doing just that in the context of showing value. JoAnn Hackos' new book (Hackos, 2006) is specifically addressed to information-developing managers who are expected to reduce costs and project time, do more work with fewer resources, and increase the value of the information they deliver.

\section{Telling stories}

You may want to tell stories, as I have done here. As Stephen Denning has shown (Denning, 2005, 2004) stories can be powerful change agents in companies. (See also, Whitney Quesenbery's chapter on storytelling in the new book on personas [Quesenbery, 
2006], as well as case studies / stories in Bias and Mayhew, 2005, 1994; Sherman, 2006; Mead, 1998; and Redish and Ramey, 1995.)

\section{Getting external recognition}

In some contexts, managers and executives are impressed when professional societies and other external groups value your work. Apply for awards. Present at conferences. Discuss your presentations and your awards within your company's intranet newsletters. Put your awards up on walls that others pass, not just in your cubicle or in your group's space.

\section{Make sure you are judged on what really matters}

As I pointed out in an earlier article on this topic (Redish, 1995), managers in personnel and accounting are not always up-to-date on what really matters for different jobs. If your annual performance evaluation is based on how many pages you've produced, but you are contributing by not producing pages, you have to get the standard for your job performance changed.

\section{Make sure your role is known when you benefit another group}

If better work by technical communicators reduces support costs, the support department may be receiving all the praise and the raises. You have to make managers and executives aware of your role in reducing support costs. Strive for collaborative situations, so that managers of other departments are not only aware of the ways that you bring value but are also eager to let others know of the value you bring to them.

\section{Conclusion}

Technical communicators and usability specialists bring value in many ways. Think about what you want, who can provide that to you, whom you have to convince before it happens, and how to convince them -- and then make that happen. 


\section{Author}

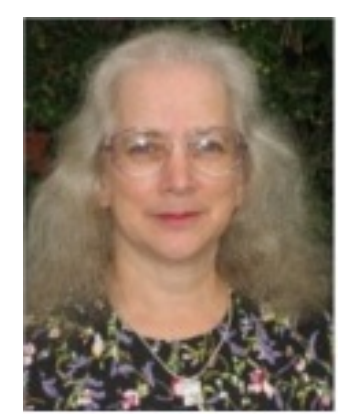

Janice (Ginny) Redish helps colleagues and clients communicate clearly. Ginny's latest book is Letting Go of the Words -- Writing Web Content that Works (Morgan Kaufmann / Elsevier, 2007) -- a very practical book in full color with many examples. More about Ginny at www.redish.net.

More about the book at: www.redish.net/writingfortheweb

\section{References}

Bias, R. and Mayhew, D. J. (Eds.), 1994, Cost-Justifying Usability, Boston: Academic Press.

Bias, R. and Mayhew, D. J. (Eds.), 2005, Cost-Justifying Usability (Second Edition): An Update for the Internet Age, San Francisco: Morgan Kaufmann.

Blackwell, C. A., 1995, A good installation guide increases user satisfaction and reduces support costs, Technical Communication, $42(1), 56-60$.

Bolling, K., 2006, The Short Tax Return : Evaluating Customer Experience and Compliance Burden, presentation to the HRMC Taxation Conference, http://www.hmrc.gov.uk/research/bolling.pdf.

Denning, S., 2005, The Leader's Guide to Storytelling: Mastering the Art and Discipline of Business Narrative, San Francisco: Jossey Bass.

Denning. S., 2004, Squirrel Inc.: A Fable of Leadership through Storytelling, San Francisco: Jossey Bass.

Friedman, T. L., 2006, The World is Flat, (updated and expanded version), NY: Farrar, Straus and Giroux.

Gabbert, J., 1996, Reducing support calls and costs at Watlow Controls, Intercom, 43 (6), June-July, 34-36. (Intercom is the 
monthly magazine of the Society for Technical Communication, www.stc.org.)

Hackos, J. T., 2006, Information Development: Managing Your Documentation Projects, Portfolio, and People, Indianapolis, IN: John Wiley \& Sons.

Jarrett, C., and Minott, C., 2004, Making a better web form, Proceedings of the Usability Professionals' Association Annual Conference, www.editingthatworks.com/making $\% 20$ a\%20better\%20web\%20for m.pdf.

Mead, J. L., 1998, Measuring the value added by technical documentation, Technical Communication, 45 (3), August, 353-379.

Quesenbery, W., 2006, Storytelling and narrative. In Pruitt, J. and Adlin, T., The Persona Lifecycle: Keeping People in Mind Throughout Product Design, San Francisco: Morgan Kaufmann, 520-555.

Redish, J. C., 1995, Adding value as a professional technical communicator, Technical Communication, 42 (1), 26-39. reprinted in Technical Communication, 50 (4), November 2003, 505-518.

Redish, J. C. and Ramey, J. A., 1995, Special section on measuring the value added by professional technical communicators, Technical Communication, 42 (1), 23-83. (Technical Communication is the quarterly journal of the Society for Technical Communication, www.stc.org.)

Sherman. P. (Ed.), 2006, Usability Success Stories: How Organizations Improve by Making Easier-to-use Software And Web Sites, Aldershot: Gower Publishing Limited.

Spencer, A. J. and Yates, D. K., 1995, A good user's guide means fewer support calls and lower support costs, Technical Communication, 42 (1), 52-55.

Theofanos, M. F. and Mulligan, C. P., 2006, Redesigning the United States Department of Health and Human Services Web Site, in P. Sherman (Ed.), Usability Success Stories: How Organizations Improve by Making Easier-to-use Software And Web Sites, Aldershot: Gower Publishing Limited, 63-92.

Theofanos, M. F., Mulligan, C. P., and Redish, J. C., 2004, Redesigning the portal of the Department of Health and Human Services, User Experience, 3 (6), Spring, 4-7. (User Experience is a 
magazine of the Usability Professionals' Association, www.usabilityprofessionals.org.)

This article was uploaded to http://www.languageatwork.eu in July of 2009 and published under a "Creative Commons license Attribution Non-commercial (by-nc)" for more information please go to: http://creativecommons.org/about/license/ 